\title{
An Analysis of the Relationship between Risk Management and Commercial Banks Performance in Jordan and the Role of the Corporate Governance and Customer Relationship Management
}

Tamer Hussain Ahmed AlQudah ${ }^{1 *}$, Professor Dr. Ahmad Shukri bin Yazid ${ }^{2}$, Diaa Khalaf Ahmed AlQatawneh ${ }^{3}$, Sameer A. A. AlZoughool ${ }^{4}$

\footnotetext{
${ }^{1,3,4}$ Phd Students, UniSZA University, Kuala Terengganu, Malaysia

${ }^{2}$ Lectrure, UniSZA University, Kuala Terengganu, Malaysia
}

DOI: $10.36347 /$ sjebm.2020.v07i01.008

| Received: 19.12.2019 | Accepted: 27.12.2019 | Published: 29.01.2020

*Corresponding author: Tamer Hussain Ahmed AlQudah

Abstract

Original Research Article

The objective of the present article is to examine the Corporate Governance (CG) activities in the commercial banking sector in Jordan and to investigate if any challenges are linked with the banking sector in adopting CG practices and how it helps them to manage risk and build customer relationship. The study uses empirical research approach by adopting secondary source for collecting data. Annual reports, online authentic news articles, past studies and customers reviews are used to investigate the topic of the study and reach the study objectives. The findings of the study reveal that the execution of CG practices in the banking sector is demonstrated as the most essential aspect because it helps to build the positive relationship with the stakeholders and help the banks to mitigate risk and use resources effectively. This study will add in the body of literature for the future researchers and facilitate the policy makers, and investors to understand the efficacy of CG activities in the context of Jordan commercial banks using stakeholder theory and institutional theory as a theoretical framework.

Keywords: Corporate Governance, Annual reports, banking sector, demonstrated.

Copyright @ 2020: This is an open-access article distributed under the terms of the Creative Commons Attribution license which permits unrestricted use, distribution, and reproduction in any medium for non-commercial use (NonCommercial, or CC-BY-NC) provided the original author and source are credited.

\section{INTRODUCTION}

Based on the significance of the commercial banking sector in the economic progression of the country [1], the central bank of the country monitors the banking situation and investigate the safe measures to strengthen the financial condition of the banks in the market and protect the rights of the stakeholders. It is also illustrated by Bruno \& Claessens [2] that the risk management is determined as a new concept in the field of banking. Thus, it is demonstrated by the practitioners that banks have well-established policies that timely recognize the risks, assess them and respond them with effective measures. In regard to the banking sector, the corporate governance mechanism offers the banks the institutional development and futuristic performance that aims to strengthen the confidence of the customers on the bank's activities, consequently the provision of funds by the depositors and investors are ensured [3]. This contributes to the success of the banks in the financial market.

In the context of Jordan commercial banks, it is stated by the researchers and practitioners that they constitute a major part of the national economy, therefore, the Board of Directors of the banks need to implement the corporate mechanism that comply with the international standards of the banking sector and also with the central bank of the Jordan [4]. According to Mersland \& Øystein Strøm [5] this practice is executed due to the financial crisis in 2008 that warned the entire world to work on their control mechanism, which could help the Board of Directors (BoD) to control the operations of the bank. In Jordan, the decision to implement the corporate governance is carried by the central banks according to the article 76 of the legislation in 2007. Moreover, according to Soltani \& Navimipour [6] it is stated that risk has fundamental role in the banking sector. While running the banking operations, various risk emanate from its operations such as credit risk, operations risk and liquidity risk that can affect the efficiency of the bank; consequently, customer services are affected. In the Jordan economy, there are various financial shocks occurred in the previous decade that has enforced banking sector to strengthen their risk process under corporate governance mechanism, which could not affect its overall performance in the market; for 
instance, financial crisis in 1989, Gulf war from 19901991 and 2003 again. Considering all these factors, the present paper has the main purpose to analyse the relationship between the corporate governance, risk management and customer relationship management in the commercial banking sector in the Jordan

\section{Research Significance}

Although there are various research studies conducted in the past to evaluate the significance of the corporate governance mechanism and risk management in the large companies or multinational organizations but a few studies are conducted in the context of the banking sector. In the Jordan, the banking sector has significant role in the economic development of the country because it contributes a major portion to the country's economy, thus, it requires a detailed analysis if the risk is effectively managed and does not harm the customer relationships and their loyalty. The literature shows that corporate governance (CG) has significant impact in the banking process because the decision makers and policy makers are pertained to bank soundness and its competitive edge in the market. Various studies have been conducted in the past to assess the CG in the banking sector in the developed economies, and a very few studies are carried out in the context of Jordan [7]. This shows gap in the previous studies that require research in the banking sector in the Jordan to assess the significance of $\mathrm{CG}$ and its overall impact on the risk management process and customer relationship. To fill this gap, the present article will have significant implications to the future researchers, investors and policy makers. It will not only contribute to the body of knowledge but will help the policy makers to formulate the policies that enforce the effective $\mathrm{CG}$ in the commercial banking sector in Jordan. In this way, the commercial banks can also enhance their overall risk management system; as a result their customer relation can be strengthened.

\section{Theoretical Framework}

The present article uses theoretical framework to explain the mechanism of CG in the context of commercial banking sector in Jordan. For this purpose, the researcher has used the theories of stakeholder and institutional theory [8]. Macey \& Miller [9] observed that for evaluating the $\mathrm{CG}$, institutional theory is widely adopted by the previous researchers because it helps to view the institution in terms of legal and regulatory system that enforce governance mechanism in the firm. In addition, stakeholder theory states that the firm has extended responsibility to the social community instead of focusing only on the shareholders such as employees, customers, dealers, government and suppliers.

To study the corporate governance in the context of stakeholder theory in banking sector employs that it is a tool that helps to understand the relationship between the groups such as customers, managers and employees of the bank. This theory helps to understand the stakeholder behaviour in the context of the firm. Another theory used in the present article is institutional theory because it enforces firms to recognize their goals and objectives in pursuit of changes in the environment [10].

\section{RESEARCH METHODOLOGY}

The present article is qualitative in nature that uses empirical research approach and secondary sources for data collection to investigate the CG practices in the commercial banking sector in the Jordan. More specifically the article examines the $\mathrm{CG}$ practices using annual reports of the commercial banks, listed on their websites and past case studies that entail the efficacy of their CG practices in terms of managing risk and developing customer relationship. A total of 10 banks are selected that are listed on the Amman Stock Exchange. In this way, it became easier to investigate and compare their CG practices. Four years data is selected for evaluating the CG practices of the Jordan commercial banks i.e. 2014-2018. Moreover, customer reviews are collected from various social media networking websites such as Twitter, LinkedIn, and Facebook about the banking operations and their experiences with the banks. In this way, it helped to examine the customer relation with the commercial banks and to understand their perspective about the risk management and CG practices of the banks.

\section{DISCUSSION}

The concept of corporate governance is discussed by various academicians and researchers in the past studies. It is defined as the set of relationship built in the company's management, BoD and other stakeholders. It helps the company to achieve its strategic objectives. CG in the banking perspective is defined as the set of activities that are carried out by the $\mathrm{BoD}$ and senior management to execute the banking operations. In summary, CG helps empower the management to build the positive relationship with its stakeholders. According to Najem \& Pan [11], CG mechanism in the Jordon is adopted in the recent years due to the increasing pressure on the accountability, monitoring and control of the bank's management in terms of managing risk related to credit and operations and effective use of resources. From the previous research studies it is revealed that $\mathrm{CG}$ mechanism have separate role in strengthening the banking operations.

It is furthermore illustrated by Shahwan \& Yousef [12], in the context of Jordan, BoDs is one of the essential components that help the banks to attain its objectives and make a bridge between those who are responsible for risk management activities and to those whom they are accountable such as customers. Directors thrive to implement positive work environment in the bank because in this way they can prevent the banks from inefficient operations, as argued by Abdullatif \& Kawuq [13]. In the country like Jordan, the external ownership of the banks are not strong, thus, 
it implies the BoD to work effectively and monitor managers on behalf of the shareholders/investors and customers. From the previous studies it is revealed that in Jordan, CG practices in the banking sector are governed by their BoDs and their ineffective performance can produce negative results to the customers [14]. Moreover, in perspective of the risk management in Jordan commercial banks, the reports reveal that the BoDs have developed audit committees that ensure the integrity of the banks and help them sustain the positive relationships with its customers. Abdullatif \& Kawuq [13] further clarified that audit committees in the Jordan banks are created to enhance the confidence in the customers about the strong corporate governance mechanism of the commercial banks. Transparency, disclosure and audit committees are demonstrated as three essential elements for good CG practices in the Jordan commercial banks argued by Ciborra \& Navarra [15].

Al-Najjar [16] also stressed that effective audit committee has fundamental role in implementing CG practices in the banking sector. It is further highlighted by Salhieh, Abu-Doleh \& Hijazi [17] that one of the main reasons for the financial distress and the bankruptcy of the banking sectors is due to inefficient audit committees. This implies that the appointed members do not work fairly in implementing the CG practices that weakens the integrity and transparency of the banks. Al-Weshah [18] further stressed that in the banking sector if the auditors do not have sufficient knowledge about the financial matters, they would not be able to reduce the risk of credits, operations and liquidity; thus, the banks' performance and efficiency will be negatively affected and so as the customers. In the given context of Jordan banks, the reports reveal that however commercial banks are considerate about CG practices and BoDs monitor their managers' activities, yet there are a few banks that have strengthened their audit committee and monitor their activities. For this purpose, the commercial banks must ensure that audit committee work in best regards of the commercial banks in Jordon [19]. And have sufficient knowledge about the accounting and financial activities of the firms.

Customer relationship management (CRM) in the context of banking sector is explained by various researchers [20,19], which stress upon the efficacy of CRM and state that it helps the companies to increase their revenue and strengthen customer value, thus the overall performance is strengthened due to enhanced service quality. In terms of the banking sector in Jordan, CRM is significantly employed by the banks, revealed by the banks reports and customer reviews. Focusing on this aspect helps the banks to build long term relationships with their customers, for instance, decision support, sales representatives and customer analyses and reporting tools are a few of the CRM practices implemented by the Jordan banks [18]. This is further illustrated by Al-Dmour et al., [21] that in Jordan commercial banks, they have efficiently managed the customer service centres that facilitate customer services and analyse their data that can help the banks to work on its risky areas such as credit terms. Those banks that have worked on CRM are increasingly gaining popularity in the Jordan banking sector, which shows the potency of CRM in building strong customer relationship in the banks. As customers are the primary element of the stakeholders, thus, they have direct relation with the firm's performance and its overall CG activities that evolve around the stakeholders [7].

\section{CONCLUSION}

The paper has a significant contribution to the existing knowledge of the literature in the context of Jordan by particularly focusing on the CG practices and its effectiveness on the firm's risk management activities and building positive CRM. The study summarizes that those commercial banks in Jordan that have effectively adopted CG practices are able to strengthen their customer relationship management. However, to manage risk factors related to the banking operations and liquidity and credit areas, BoDs who are responsible for carrying out $\mathrm{CG}$ practices in the banking sector in Jordan must employ efficient audit committee that have appropriate knowledge about the accounting and financial areas and enhance the integrity and accountability of the banks to its stakeholders. The findings of the study is however consistent with the previous studies that shows the positive relationship between the $\mathrm{CG}$ practices, risk management and CRM of the banking sector, yet the present study contributes that in the context of the Jordan banking sector, BoDs must employ skilful audit committee that enhance the accountability and CG practices of the banks.

\section{REFERENCES}

1. De Haan J, Vlahu R. Corporate governance of banks: A survey. Journal of Economic Surveys. 2016 Apr;30(2):228-77.

2. Bruno V, Claessens S. Corporate governance and regulation: can there be too much of a good thing? Journal of Financial Intermediation, 2010;19(4):461-482.

3. Bonin JP, Hasan I, Wachtel P. Privatization matters: Bank efficiency in transition countries. Journal of Banking \& Finance. 2005 Aug 1;29(89):2155-78.

4. De Simone A. Governance Structure, Risk an Performance in the European Banking Sector: an Empirical Analysis. Aestimatio. 2012(4):116-143.

5. Mersland R, Strøm R $\varnothing$. Performance and governance in microfinance institutions. Journal of Banking \& Finance. 2009 Apr 1;33(4):662-9.

6. Soltani Z, Navimipour NJ. Customer relationship management mechanisms: A systematic review of the state of the art literature and recommendations for future research. Computers in Human Behavior. 2016 Aug 1;61:667-88. 
7. Abu Qa'dan MB, Suwaidan MS. Board composition, ownership structure and corporate social responsibility disclosure: the case of Jordan. Social Responsibility Journal. 2019 Feb 4;15(1):28-46.

8. Latiefa \& Abdali. The role and place of risk management in the economic status of the institution of cement and its derivatives, Case study in the province of Saeeda. Master Thesis, Abu Bakr University, Algeria. 2012.

9. Macey JR, Miller GP. Corporate governance and commercial banking: A comparative examination of Germany, Japan, and the United States. Stanford Law Review. 1995 Nov 1:73-112.

10. Grove $\mathrm{H}$, Patelli L, Victoravich LM, Xu P. Corporate governance and performance in the wake of the financial crisis: Evidence from US commercial banks. Corporate Governance: An International Review. 2011 Sep;19(5):418-36.

11. Najim B. Integrative Role of Internal Audit in the Effectiveness of Institutional Control a Prospective Study in A Sample of Iraqi Banks and Companies. Economic Journal, University of Basra. 2013;24:16-17

12. Shahwan \& Yousef. The impact of the application of the principles of corporate governance on the financial performance of the companies listed on the ASE general contribution, Master Thesis, Faculty of Economics and Administrative Sciences, Zarqa University, Jordan. 2013.

13. Abdullatif M, Kawuq S. The role of internal auditing in risk management: evidence from banks in Jordan. Journal of Economic and Administrative Sciences. 2015 May 18;31(1):30-50.

14. Tomar S, Bino A. Corporate governance and bank performance: evidence from Jordanian banking industry. Jordan Journal of Business Administration. 2012 Apr;153(655):1-40.

15. Ciborra C, Navarra DD. Good governance, development theory, and aid policy: Risks and challenges of e-government in Jordan. Information technology for development. $2005 \mathrm{Apr}$ 1;11(2):141-59.

16. Al-Najjar B. Corporate governance and institutional ownership: evidence from Jordan. Corporate Governance: The international journal of business in society. 2010 Apr 13;10(2):176-90.

17. Salhieh L, Abu-Doleh J, Hijazi N. The assessment of e-banking readiness in Jordan. International Journal of Islamic and Middle Eastern Finance and Management. 2011 Nov 22;4(4):325-42.

18. Al-Weshah GA. Marketing intelligence and customer relationships: empirical evidence from Jordanian banks. Journal of Marketing Analytics. 2017 Dec 1;5(3-4):141-52.

19. Stanwick PA, Stanwick SD. The relationship between corporate governance and financial performance. Journal of Corporate Citizenship. 2002;8(4):35-48.

20. Alalwan AA, Dwivedi YK, Rana NP, Williams MD. Consumer adoption of mobile banking in Jordan: examining the role of usefulness, ease of use, perceived risk and self-efficacy. Journal of Enterprise Information Management. 2016 Feb 8;29(1):118-39.

21. Al-Dmour HH, Algharabat RS, Khawaja R, AlDmour RH. Investigating the impact of ECRM success factors on business performance: Jordanian commercial banks. Asia Pacific Journal of Marketing and Logistics. 2019 Jan 14;31(1):105-27. 